\title{
EXPERIMENTAL AND FEA ANALYSIS OF COMPOSITE LEAF SPRING BY VARYING THICKNESS
}

\author{
Sagar B Mahajan ${ }^{1}$, M.C.Swami ${ }^{2}$, Parmeshwar Patil ${ }^{3}$ \\ ${ }^{I}$ M.E. Machine Design Student, Mechanical Department, M. S. Bidve Engineering College, Latur, Maharashtra, India \\ ${ }^{2}$ Assistant professor, Mechanical Department, M. S. Bidve Engineering College, Latur, Maharashtra, India \\ ${ }^{3}$ Assistant professor, Mechanical Department, G. N. D. Engineering College, Bidar, Karnataka, India.
}

\begin{abstract}
The work is carried out on composite leaf spring of a commercial vehicle. The objective of this work is to carryout design and analysis of composite leaf spring with experimental design consideration and loading condition. The material of leaf spring is EGFRC (Glass Fiber reinforced composite). The GFRC leaf springs are manufactured by hand lay-up method which were evaluated and study. The model of composite leaf spring is prepared and analyzed using ANSYS14.5 for the deflection and stresses under defined loading condition. The experimental and FEA result compared for validation. The dimension of conventional leaf spring is taken with varying thickness for evaluation of result and Static analysis is performed
\end{abstract}

Keywords: E-glass/epoxy composite, ANSYS14.5, Static Analysis.

\section{INTRODUCTION}

Automotive industries need tremendous amount of metal, alloys for producing different parts of the vehicle. The replacement of metals was a distant dream but due to rapid development in glass, polymers, ceramics, synthetic fibers and some organic and inorganic substances have been proved as the turning point [1]. More interesting aspect is, by combining two or more materials one can obtain improved mechanical properties of materials. Composites have better properties such as high specific strength, stiffness and hardness [2]. Due to the mentioned properties composite find wide range of applications not only with respect to properties but also with its weight and cost effectiveness. One such application is composite leaf spring [3]. Leaf springs are mainly used in suspension systems to absorb shock loads in automobiles like light motor vehicles, heavy duty trucks and in rail systems. It carries lateral loads, brake torque, driving torque in addition to shock absorbing. The advantage of leaf spring over helical spring is that the ends of the spring may be guided along a definite path as it deflects to act as a structural member in addition to energy absorbing device. According to the studies made a material with maximum strength and minimum modulus of elasticity in the longitudinal direction is the most suitable material for a leaf spring [4].

In this analysis GFRC leaf spring is compared with varying thickness [5]. Static testing condition is applied and result are compared by creating virtual models of composite leaf spring.

\section{MAREAIAL PROPERTIES AND DESIGN SPECIFICATION}

Glass fiber reinforced plastics is a composite material in which the volume fraction of fiber is $70 \%$ considering rule of mixture [6]. The low density and high specific strain of composites provides high specific strain energy capacity [7].

Table-1 Properties of composite leaf spring

\begin{tabular}{|l|l|}
\hline Parameter & Value \\
\hline Longitudinal Elastic Modulus, $\mathrm{E}_{1}$ & $60.52 \mathrm{Gpa}$ \\
\hline Transverse elastic modulus, $\mathrm{E}_{2}$ & $10.37 \mathrm{Gpa}$ \\
\hline Major poission's Ratio, $\mathrm{V}_{12}$ & 0.230 \\
\hline Minor poission's Ratio, $\mathrm{V}_{21}$ & 0.0390 \\
\hline In plane shear Modulus, $\mathrm{G}_{12}$ & $4.014 \mathrm{Gpa}$ \\
\hline Density & $2110 \mathrm{Kg} / \mathrm{m}^{3}$ \\
\hline
\end{tabular}

The glass fiber are earliest know fiber used in reinforcement. The main advantage of glass fiber reinforced composite is low cost, high strength, high chemical resistance and good insulating properties however the main disadvantage of glass fiber in composite is low elastic modulus poor adhesion polymer[8] 


\subsection{Selection of Fiber}

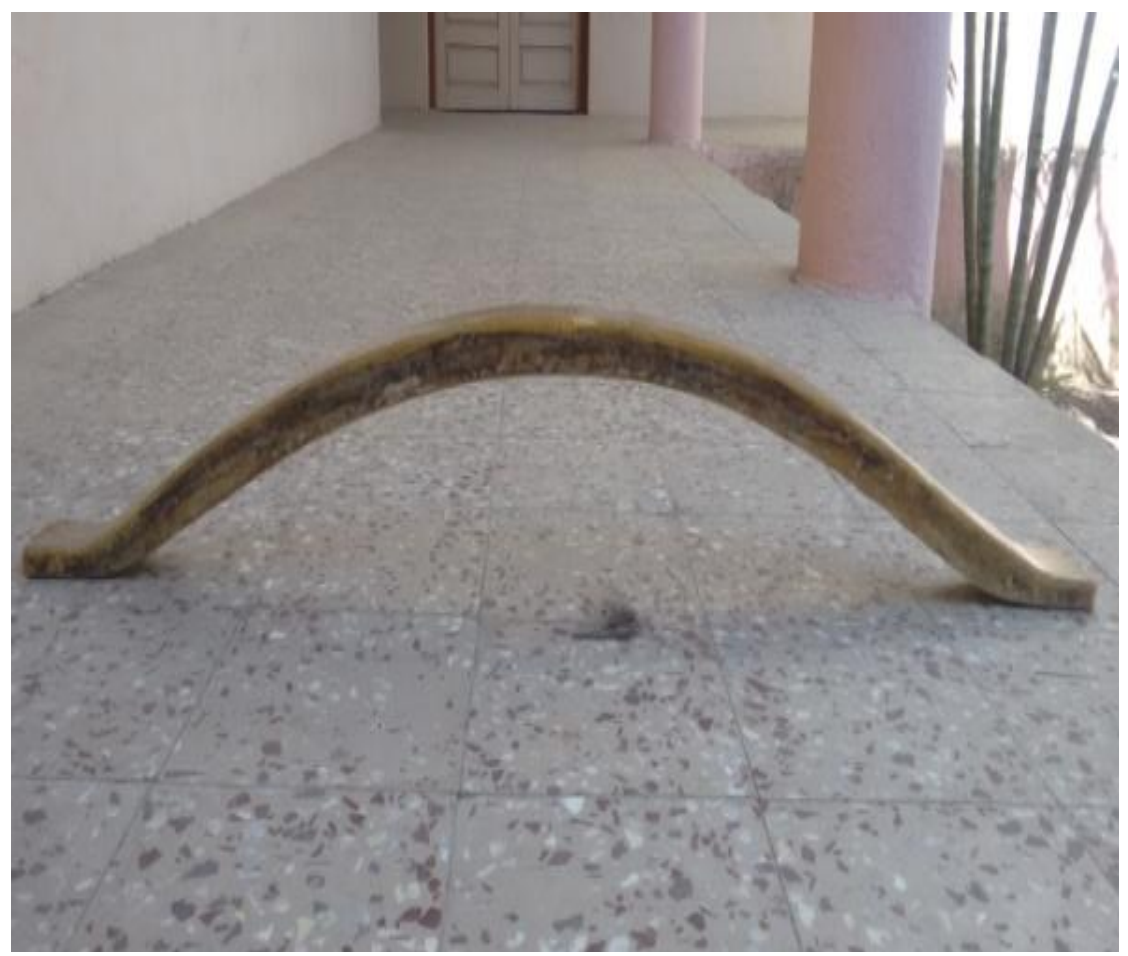

Fig-1 Fibricated composite Leaf Spring

Table-2 .Properties of fiber

\begin{tabular}{|l|l|l|}
\hline Sr.No. & $\begin{array}{l}\text { Type of } \\
\text { Fiber }\end{array}$ & Properties \\
\hline 1 & $\begin{array}{l}\text { Glass } \\
\text { Fiber }\end{array}$ & - \\
\hline a) & E-glass & $\begin{array}{l}\text { High Stiffness, high buckling, } \\
\text { weak in shear, low cost. }\end{array}$ \\
\hline b) & S-glass & $\begin{array}{l}\text { High Stiffness, high buckling, } \\
\text { weak in shear, high cost. }\end{array}$ \\
\hline 2 & $\begin{array}{l}\text { Carbon } \\
\text { fiber }\end{array}$ & $\begin{array}{l}\text { High strength, high modulus, } \\
\text { low density, high temperature } \\
\text { resistance, considerably high } \\
\text { cost. }\end{array}$ \\
\hline 3 & Ceramic & $\begin{array}{l}\text { High temperature resistance, } \\
\text { low thermal conductivity. }\end{array}$ \\
\hline
\end{tabular}

From the above table we are choosing the E-glass fiber and resin epoxy Choosing for fabrication of composite leaf spring.

\subsection{Design Specification of Composite Leaf Spring}

The leaf spring behaves like a cantilever beam. It is subjected to bending stresses, longitudinal and transverse shear stress. The spring is designed on the basis of constant width and Varying thickness. Leaf spring is manufactured by hand lay-up technique as shown in fig. 1. It is more suitable and economical compared to filament winding technique as the cross-section area is constant throughout the leaf spring. The specification for the spring is as follows: Total length of the spring is $=1010 \mathrm{~mm}$, Thickness $=$ $28,30,32 \mathrm{~mm}$, Width $=45 \mathrm{~mm}$.

\section{RESULT AND DUSCUSSION}

\subsection{Experimental \& Analytical Results}

Experimental analysis of the leaf spring is done on Universal Testing Machine[6]. Glass fiber composite leaf spring is tested on the same. Load is applied at the center of the spring. The load is applied in a gradual intervals of $50 \mathrm{~kg}$. The table 3 shows experimental and analytical results at a load of $300 \mathrm{~kg}$.

Table- 3 Experimental \& Analytical results at -load 300kg for stress and deflection of GFRC

\begin{tabular}{|l|l|l|l|l|}
\hline \multirow{2}{*}{$\begin{array}{l}\text { Thickne } \\
\text { ss mm }\end{array}$} & \multicolumn{3}{|l|}{ Analytical result } & \multicolumn{2}{l|}{$\begin{array}{l}\text { Experimental } \\
\text { result }\end{array}$} \\
\cline { 2 - 5 } & $\begin{array}{l}\text { Deflectio } \\
\text { n mm }\end{array}$ & $\begin{array}{l}\text { Stresses } \\
\text { N/mm }\end{array}$ & $\begin{array}{l}\text { Deflect } \\
\text { ion } \\
\text { mm }\end{array}$ & $\begin{array}{l}\text { Stresses } \\
\text { N/mm }\end{array}$ \\
\hline 28 & 128.97 & 252.75 & 92 & 252.10 \\
\hline 30 & 104.85 & 220.18 & 75 & 220.15 \\
\hline 32 & 86.40 & 193.51 & 61 & 193.30 \\
\hline
\end{tabular}

\subsection{D-Finite Element Analysis (FEA)}

For 3D finite element analysis of present work is done in Ansys 14.5 using a 3D element suitable for composite analysis known as "SOLID 186" and is an 20-noded element useful for structural analysis of composite which facilitates near about 250 layers. 


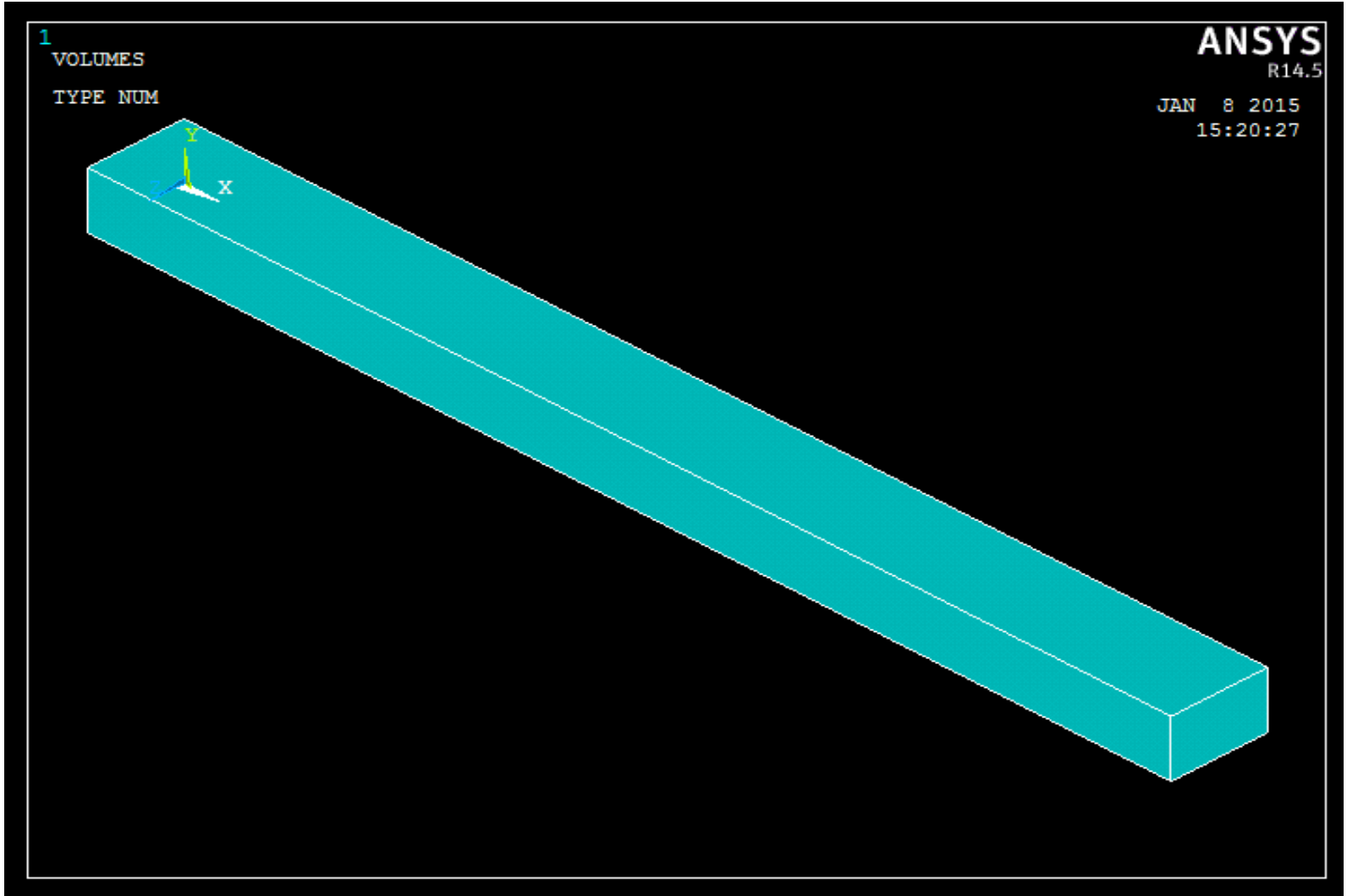

Fig-2: 3-D Model of leaf spring

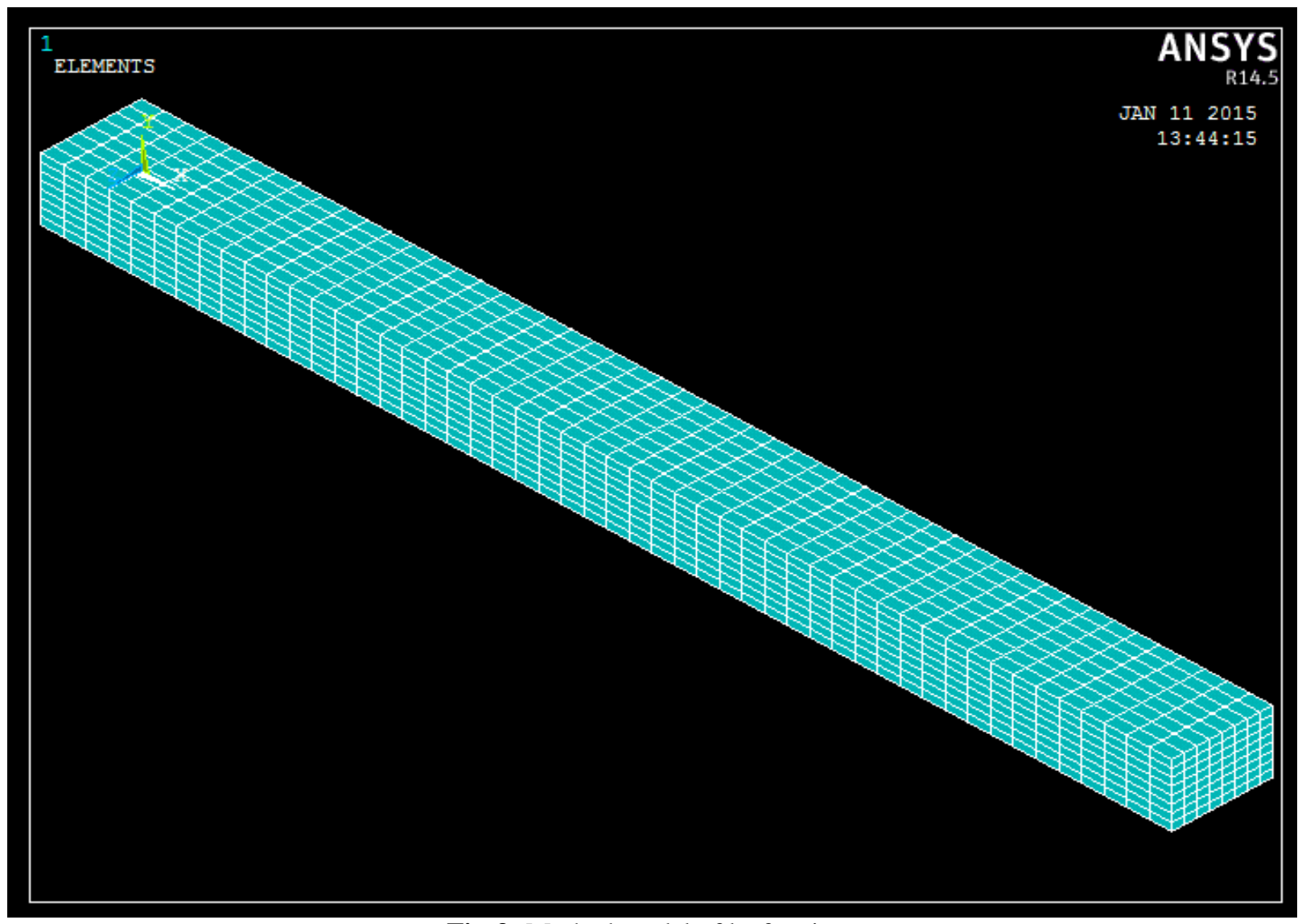

Fig-3: Meshed model of leaf spring 
For the leaf spring is consider as cantilever beam with one end fixed and at other end load applied shown in fig4.

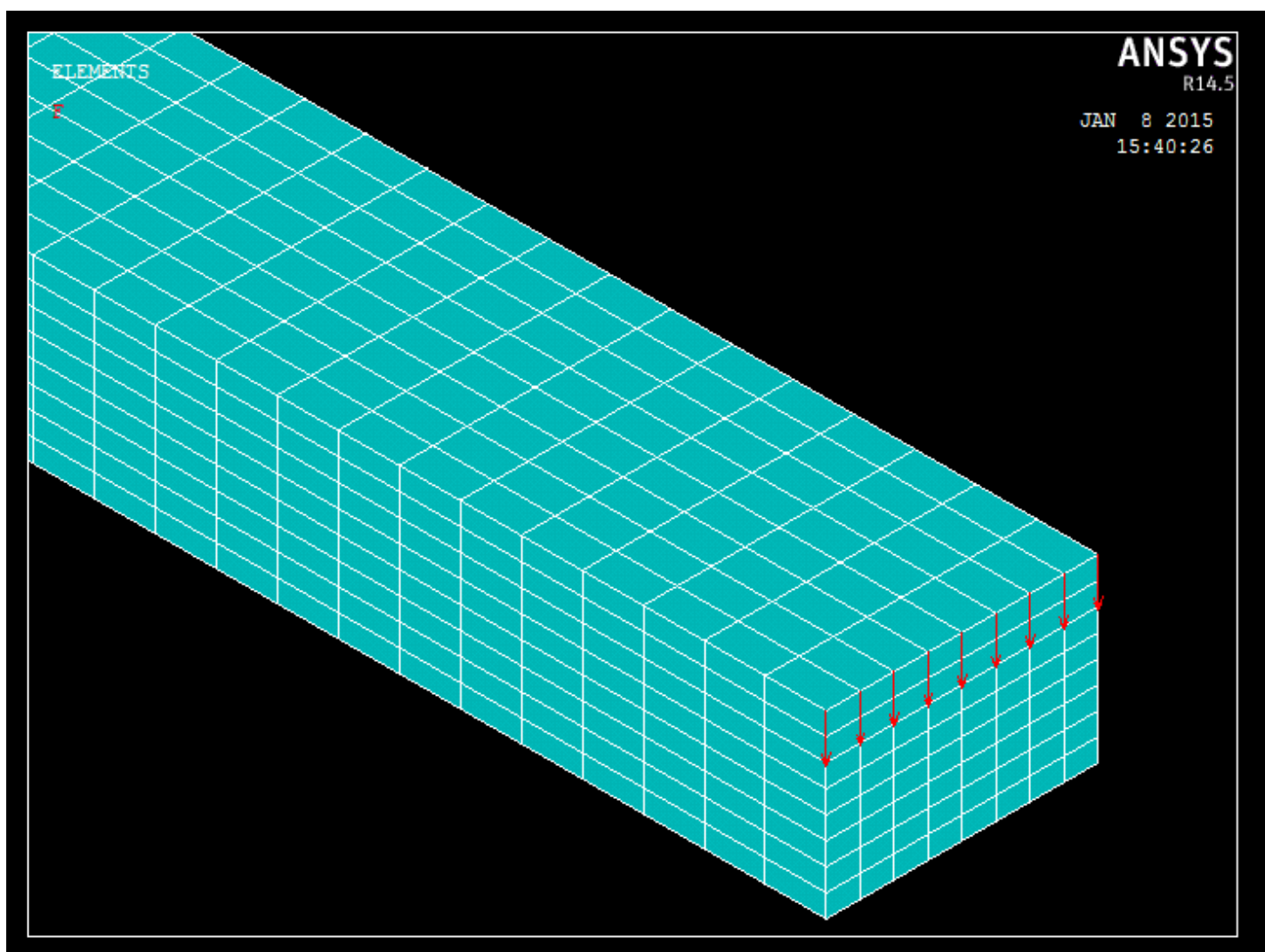

Fig-4: Fixed support with load

\subsection{Deflection for composite leaf spring at varying thickness.}

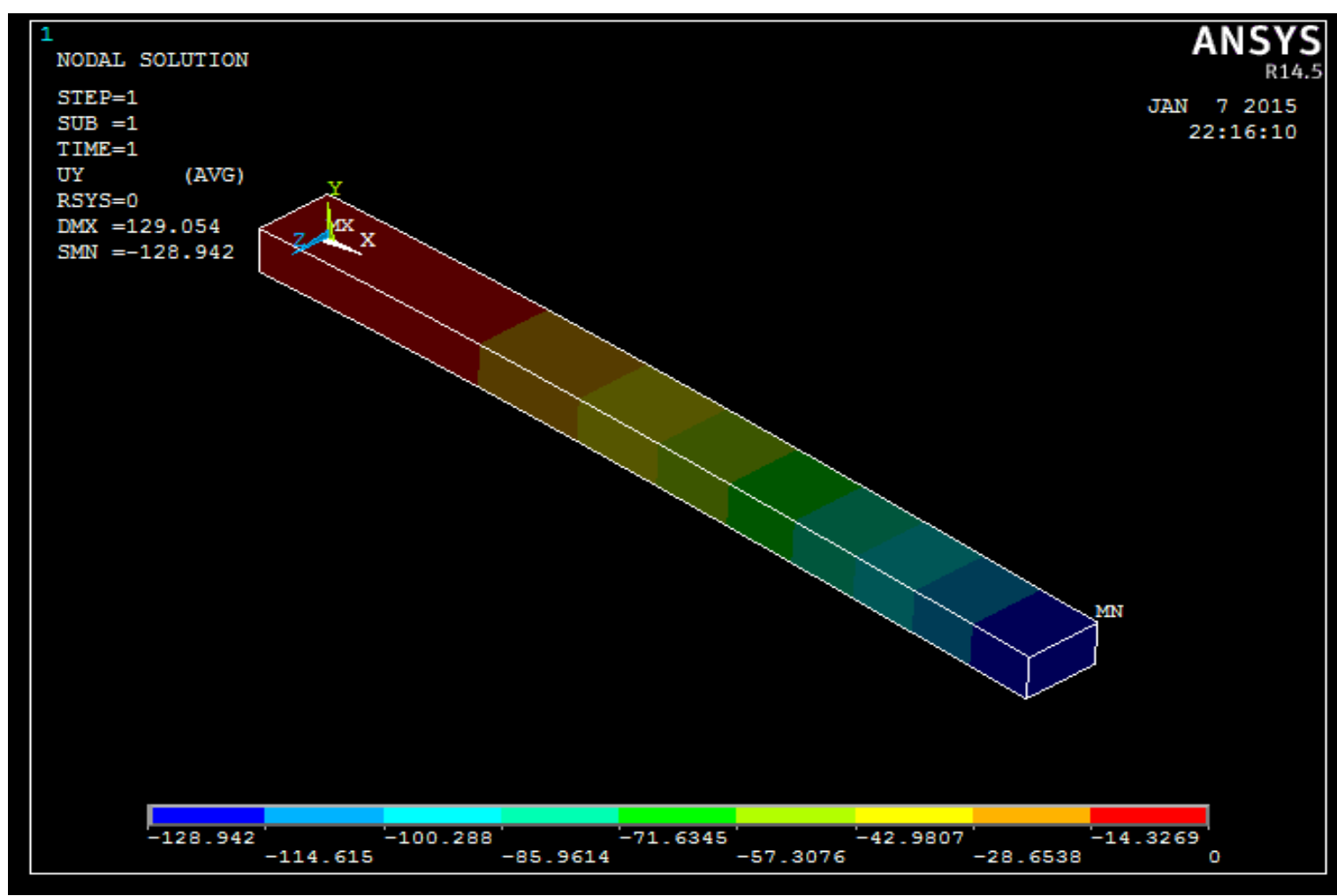

Fig-5: Deflection of Composite leaf spring at thickness $28 \mathrm{~mm}$ 


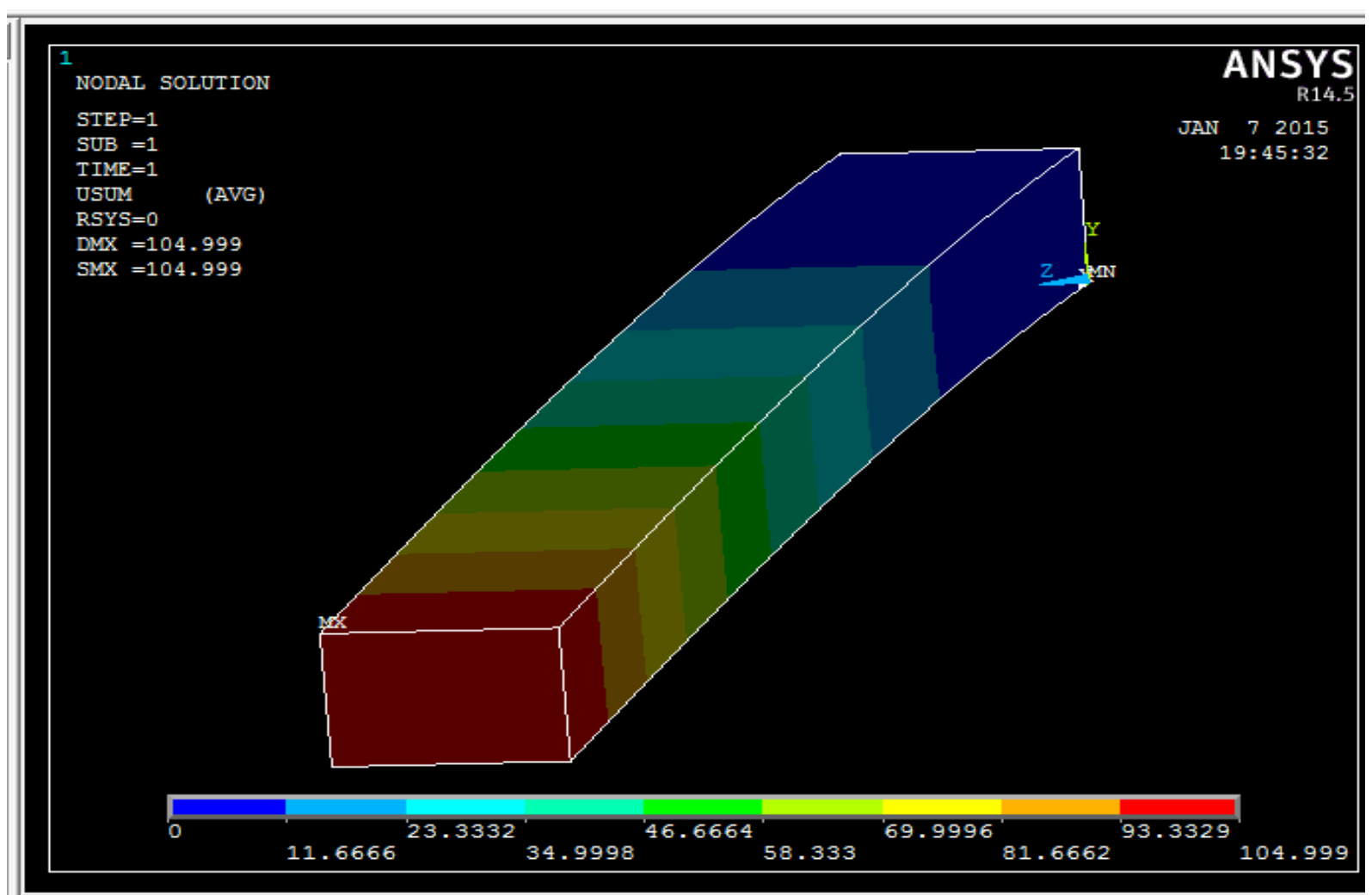

Fig-6: Deflection of Composite leaf spring at thickness $30 \mathrm{~mm}$

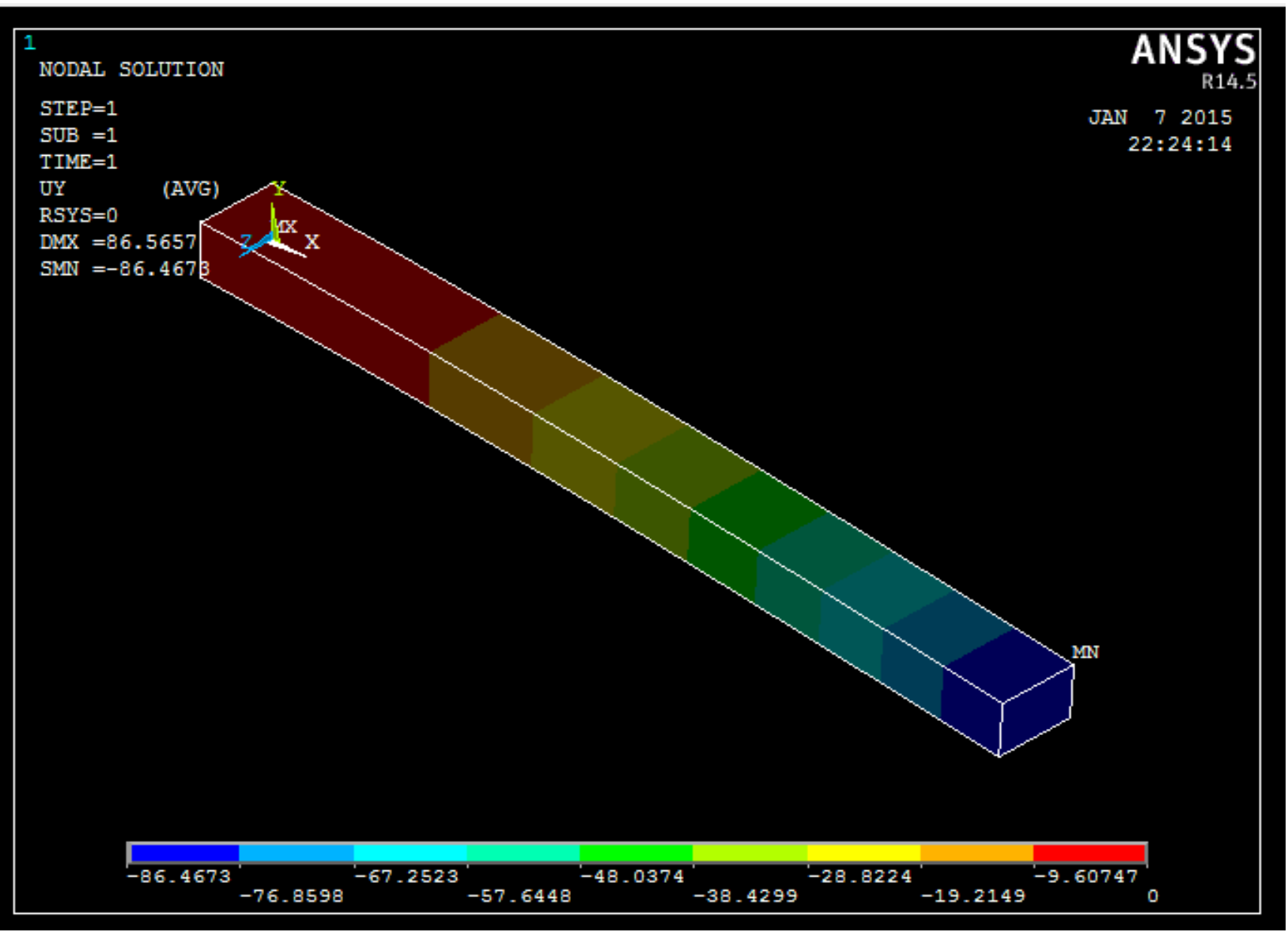

Fig-7: Deflection of Composite leaf spring at thickness 32mm

Fig-5, 6, 7 shows the deflection result of composite leaf is less as compared to conventional leaf spring. 
Table-4: FEA results at load 300kg deflection of Composite leaf spring at thickness $28 \mathrm{~mm}, 30 \mathrm{~mm}$ and $32 \mathrm{~mm}$.

\begin{tabular}{|l|l|l|}
\hline \multirow{2}{*}{$\begin{array}{l}\text { Thickness } \\
\mathbf{m m}\end{array}$} & \multicolumn{2}{|l|}{ Deflection $\mathbf{m m}$} \\
\cline { 2 - 3 } 28 & Steel & Composite \\
\hline $\mathbf{3 0}$ & $\mathbf{1 5 2 . 5 2}$ & $\mathbf{1 2 9 . 0 5 4}$ \\
\hline 32 & $\mathbf{1 1 9 . 4 9}$ & $\mathbf{1 0 4 . 9 9 9}$ \\
\hline
\end{tabular}

\subsection{Stress for Composite Leaf Spring at Varying Thickness}

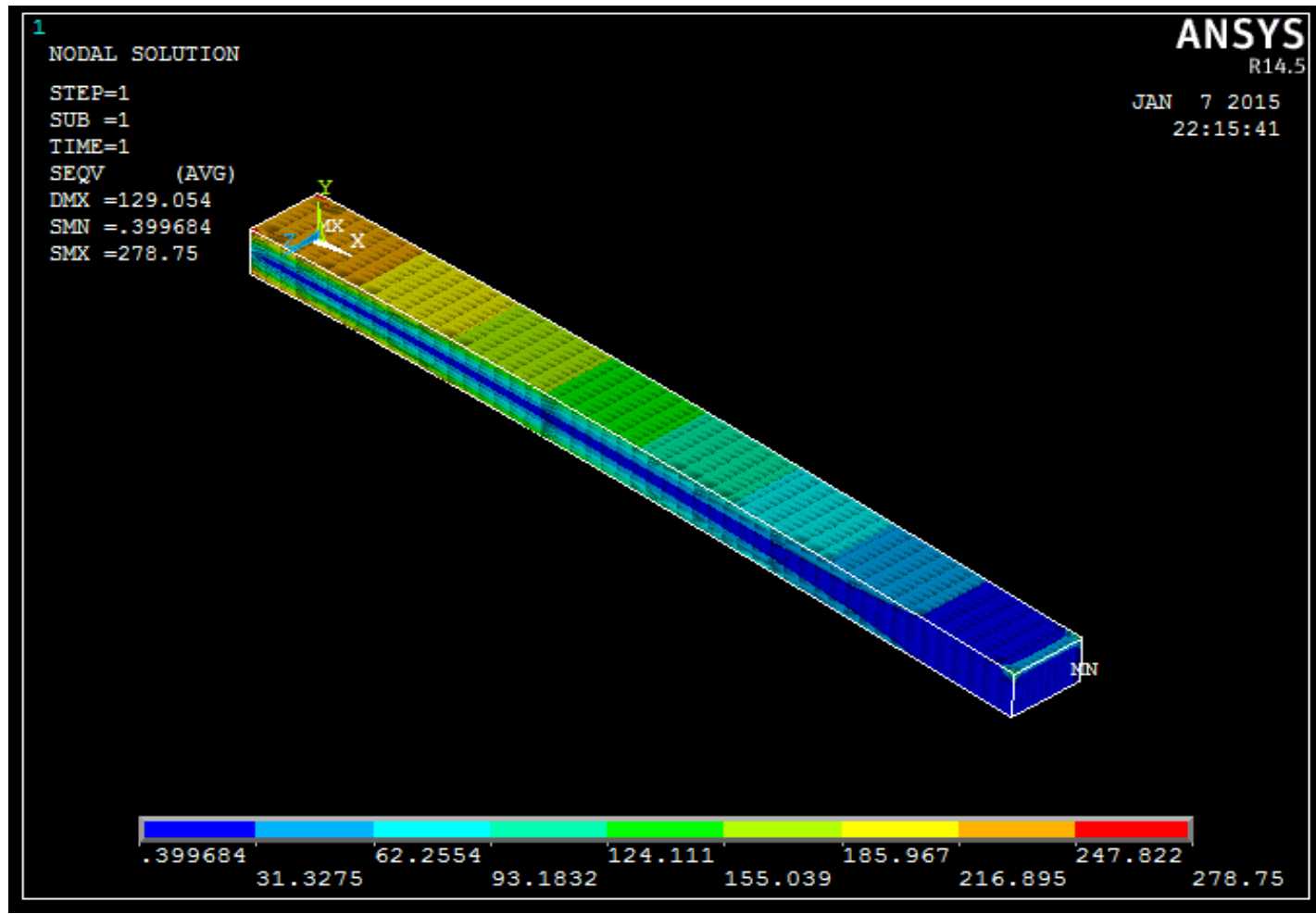

Fig-8: Stress of Composite leaf spring at thickness $28 \mathrm{~mm}$

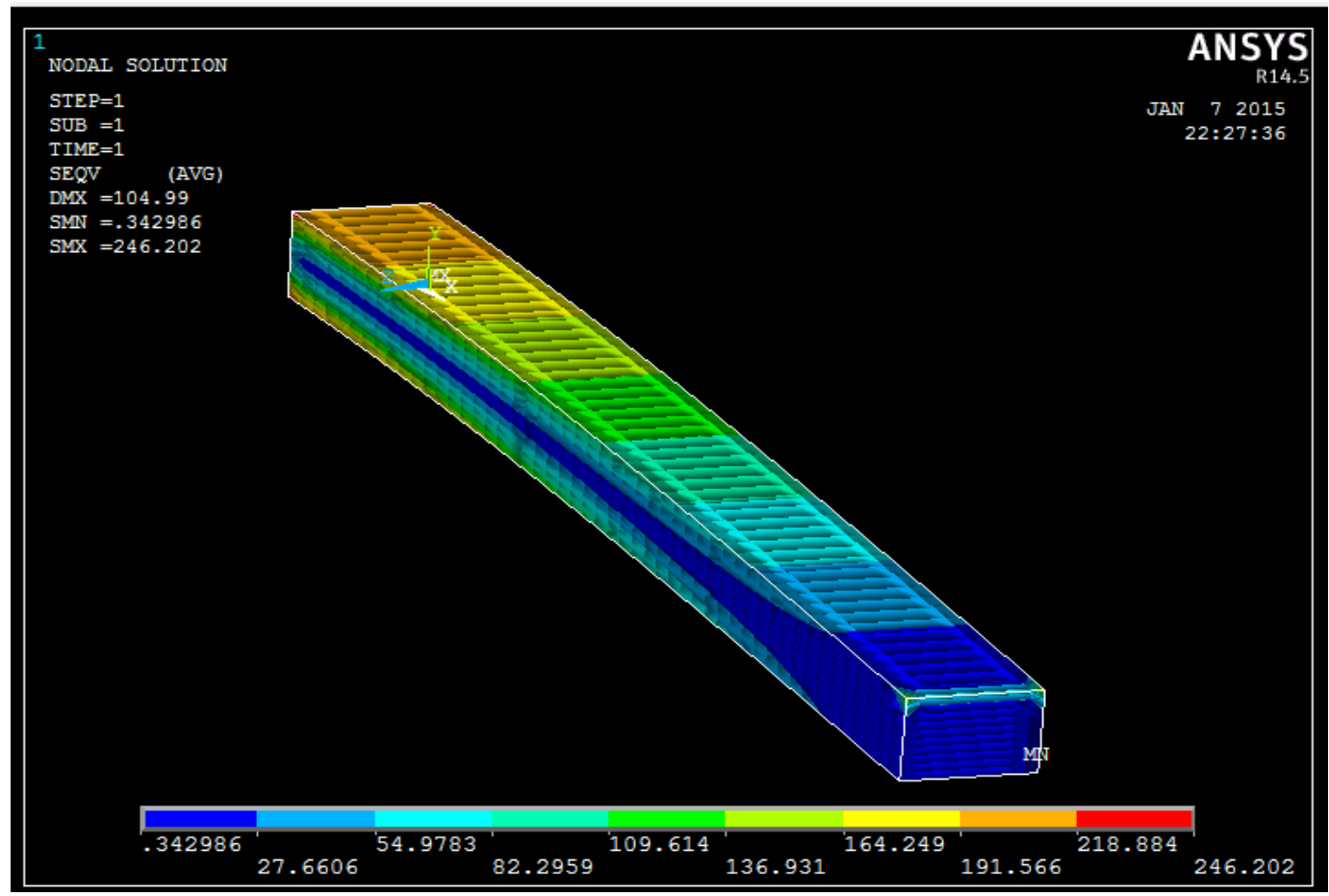

Fig-9: Stress of Composite leaf spring at thickness 30mm 


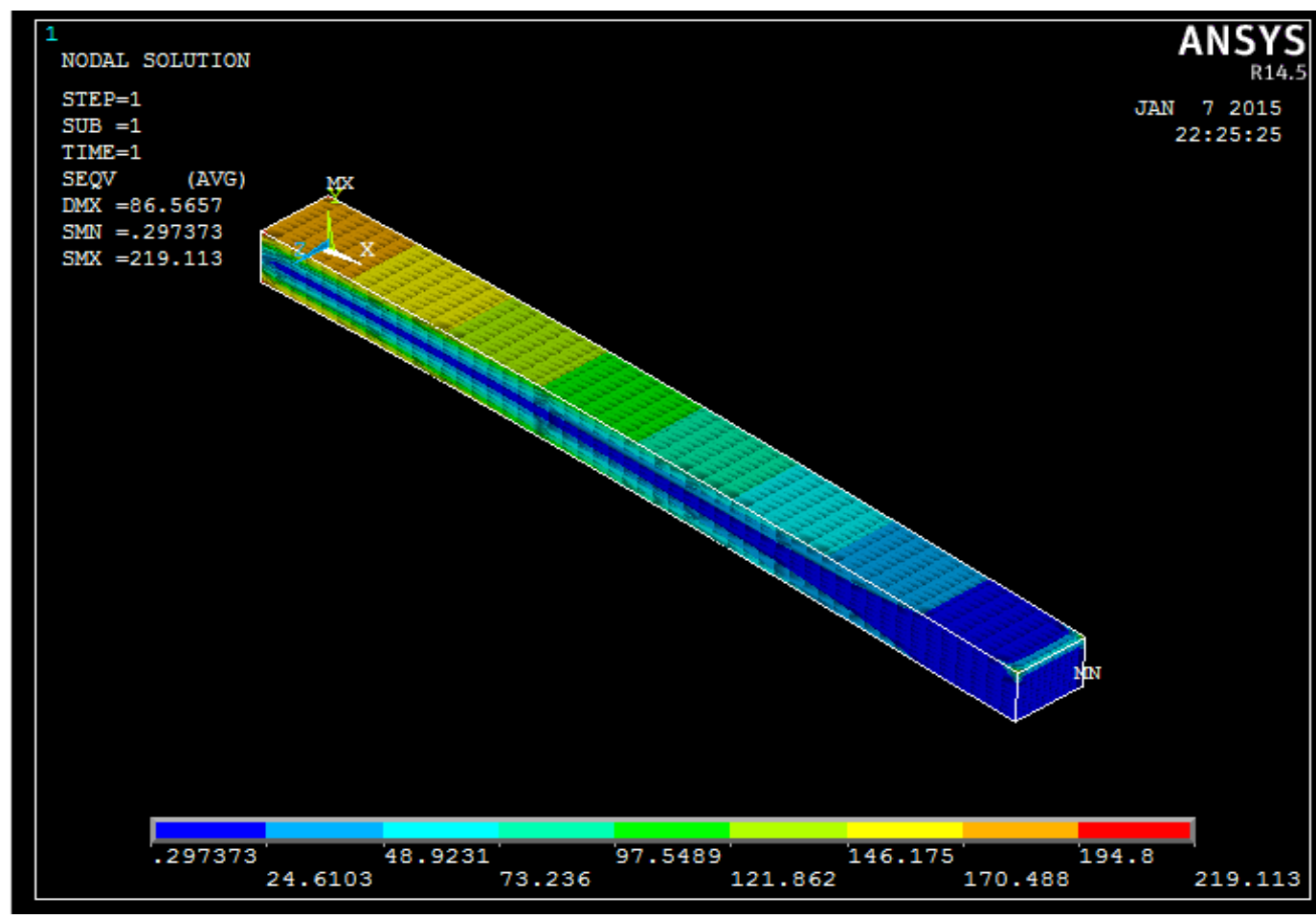

Fig-10: Stress of Composite leaf spring at thickness 32mm

Fig- 8, 9, 10 shows the stresses result of composite leaf spring much lower as compared to conventional leaf spring at various thicknesses.

Table-5: FEA results at load 300kg Stresses of Composite leaf spring at thickness $28 \mathrm{~mm}, 30 \mathrm{~mm}$ and $32 \mathrm{~mm}$

\begin{tabular}{|l|l|l|}
\hline \multirow{2}{*}{$\begin{array}{l}\text { Thickness } \\
\text { mm }\end{array}$} & \multicolumn{2}{|l|}{ Deflection $\mathbf{~ m m}$} \\
\cline { 2 - 3 } & Steel & Composite \\
\hline 28 & 875.97 & $\mathbf{2 7 8 . 8 5}$ \\
\hline 30 & 741.29 & 246.20 \\
\hline 32 & 651.27 & 219.11 \\
\hline
\end{tabular}

\subsection{Graphical comparison of conventional and composite leaf spring}

\subsubsection{Thickness Vs Deflection}

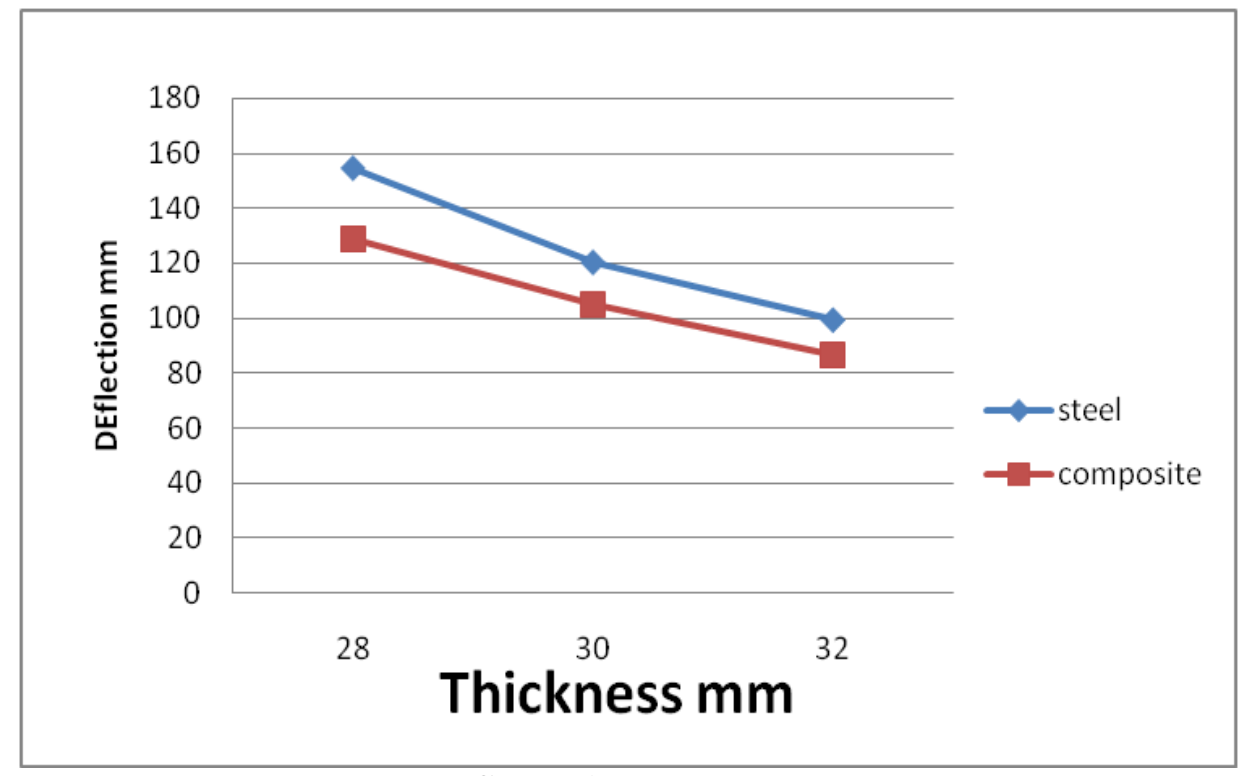

Graph-1: FEA Result 


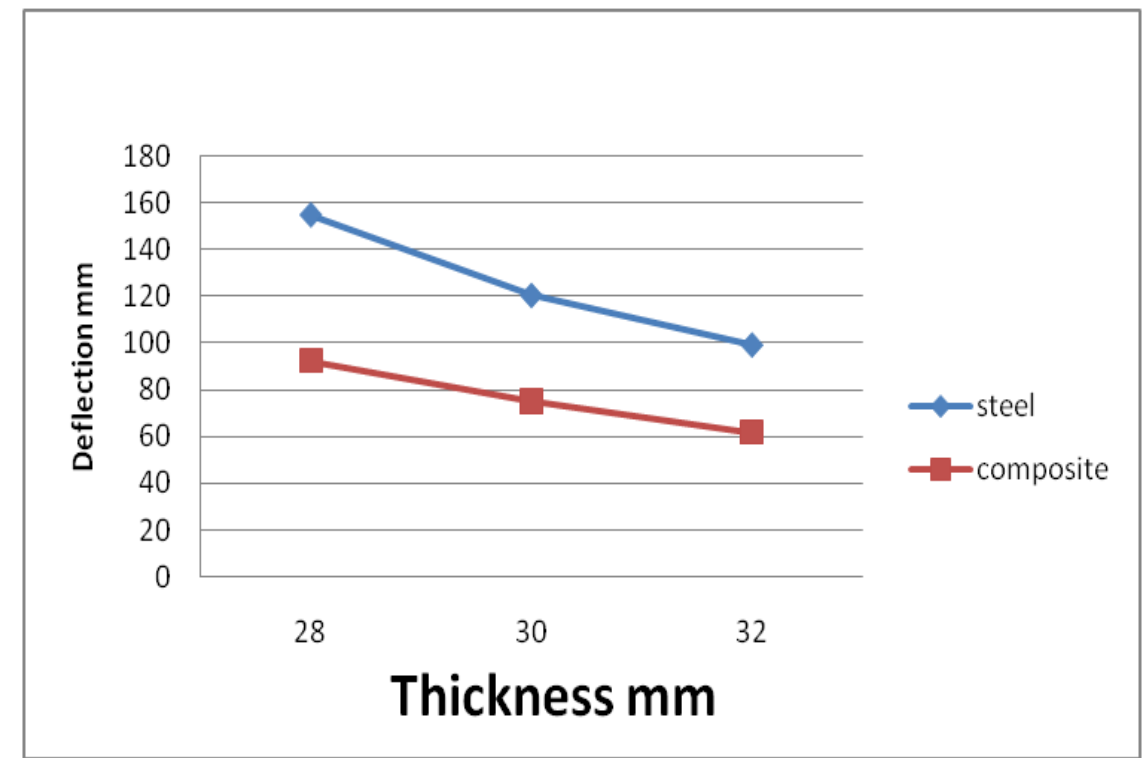

Graph-2: Experimental Result

\subsubsection{Thickness Vs Stresses}

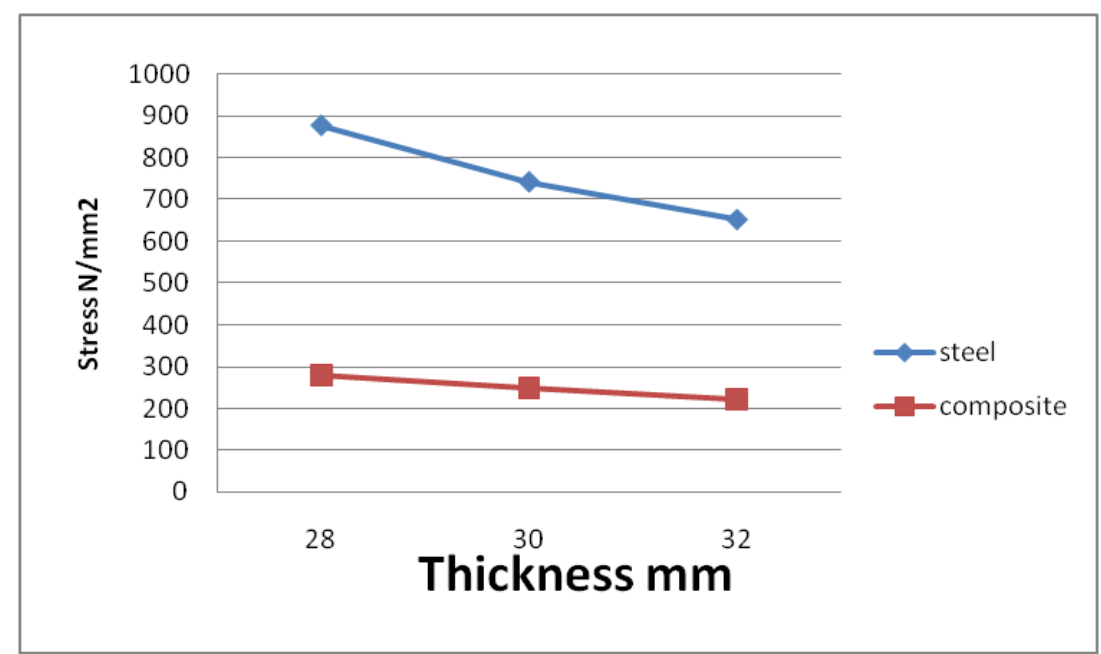

Graph-3: FEA Result

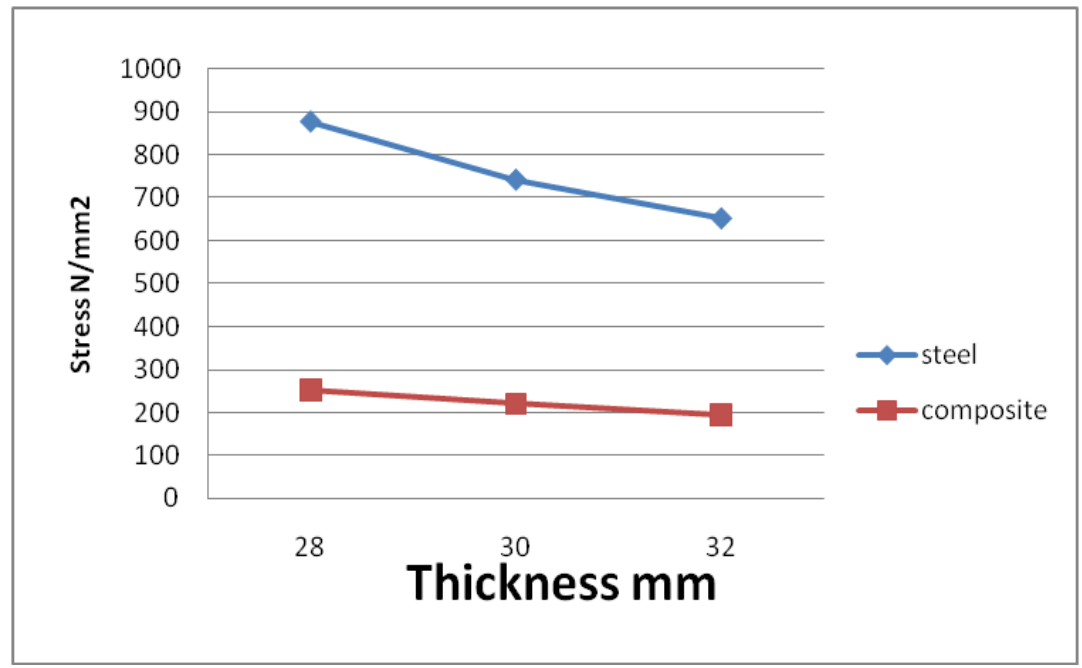

Graph-4: Experimental Result

The above graph shows the great difference between the conventional leaf spring and composite leaf spring. 


\section{CONCLUSION}

In the present research work a comparative study has been made of GFRC by varying thickness. GFRC leaf spring have been successfully fabricated by simple hand lay-up technique. Under static loading condition Defelction and stresses of GFRC are found with great difference with varying thickness.

\section{FUTURE SCOPE}

a) Analysis of leaf spring is done by varying width and varying thickness

b) Harmonic analysis with finding and compression of first five natural Frequencies.

c) As this analysis is under static load condition, so one can go for the analysis of composite \& steel leaf spring under dynamic loading condition

\section{ACKNOWLEDGEMENTS}

I would like to thank Prof.M.C.Swami for Motivating me to undertake the project in comparative study of leaf springs. I would also like to thank, Prof.S.G.Mantri, Prof.K.S.Upase, Londhe A.B providing me the Technical Knowledge about this project.

\section{REFERENCES}

[1]. V L Narayana (2012), Design and Analysis Of Mono Composite Leaf Spring For Suspension in Automobiles, Int. J. Eng. Res. \& Tech., 1, 6, pp.1-13.

[2]. B Mehdi and B Majid (2012), Optimization of Steel Helical Spring by Composite Spring, Int. J. Multidisciplinary Sci. Engg., 3, 6, pp. 47-51.

[3]. M K Alwan, Q A Hama and M A Tariq (2011), The Polymer Composite Beam Reinforced by Natural Jute Fiber, Engg. Tech. J., 29, 1, pp.1-12.

[4]. Pankaj Saini ${ }^{1}$, Ashish Goel ${ }^{2}$, Dushyant Kumar ${ }^{3}{ }^{1,2},{ }^{3}$ B. Tech 4th Year Student, Department of ME, Moradabad Institute of Technology, Moradabad, Uttar Pradesh, INDIA, Design and analysis of composite leaf spring for light vehicles International Journal of Innovative Research in Science, Engineering and Technology Vol. 2, Issue 5, May 2013pp-1.

[5]. Sagar B Mahajan1, Prof.M.C.Swami2 , Permeshwar Patil3 Design and Analysis of Mono Composite Leaf Spring by Varying Thickness using FEA IOSR Journal of Mechanical and Civil Engineering (IOSR-JMCE) e-ISSN: 2278-1684,p-ISSN: 2320-334X, Volume 12, Issue 1 Ver. II (Jan- Feb. 2015), PP 51-56.

[6]. Y N V Santhosh Kumar and M Vimal Teja (2012), Design and Analysis of Composite Leaf Spring, Int. J. Mech. Ind. Engg, 2, 1, pp. 2231-2247.

[7]. Pozhilarasu1* and $\mathrm{T}$ Parameshwaran Pillai1, Corresponding Author: V Pozhilarasu $\square$ pozhilarasu@gmail.com Performance analysis of steel leaf spring with composite leaf spring and fabrication of composite leaf spring ,Int. J. Engg. Res. \& Sci. \& Tech. 2013 ISSN 2319-5991 www.ijerst.com vol. 2, No. 3, August 2013@ 2013 IJERST pp-102-109
[8]. William D. Callister Material science and engineering. [9]. Parkhe Ravindra, Mhaske Raman, Belkar Sanjay, Modeling and Analysis of Carbon Fiber Epoxy Based Leaf Spring under the Static Load Condition by Using FEA International Journal of Emerging Science and Engineering (IJESE) ISSN: 2319-6378, Volume-2, Issue-4, February 2014 pp-39-42.

[10]. Jadhav Mahesh V, Zoman Digambar B, Y R Kharde, R R Kharde Performance Analysis of Two Mono Leaf Spring Used For Maruti 800 Vehicle ,International Journal of Innovative Technology and Exploring Engineering (IJITEE) ISSN: 2278-3075, Volume-2, Issue-1, December 2012 pp65-70.

[11]. Ghodake A. P.*, Patil K.N. Department of Mechanical Engineering, SND COE \& RC Yeola, Nashik, India, Analysis of Steel and Composite Leaf Spring for Vehicle, IOSR Journal of Mechanical and Civil Engineering (IOSRJMCE) e-ISSN: 2278-1684 Volume 5, Issue 4 (Jan. - Feb. 2013), PP 68-76 www.iosrjournals.org.

[12]. Nisar S. Shaikh, S.M. Rajmane, Modelling and Analysis of Suspension System of TATA SUMO by using Composite Material under the Static Load Condition by using FEA, International Journal of Engineering and Advanced Technology (IJEAT) ISSN: 2249 - 8958, Volume-3, Issue-3, February 2014 pp-53-60

\section{BIOGRAPHIES}

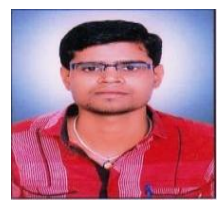

Mr. Sagar B.Mahajan, (Student of M.E. Machine Design)

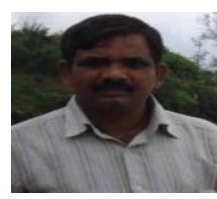

Prof. M. C. Swami, Assistant Professor

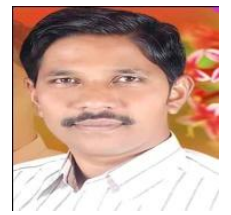

Prof. P. S. Patil, Assistant Professor 